\title{
Effects of simulated herbivory and resource availability on native and invasive exotic tree seedlings
}

\author{
William E. Rogers*, Evan Siemann \\ Department of Ecology and Evolutionary Biology, Rice University, Houston, USA
}

Received: September $2001 \cdot$ Accepted: February 2002

\begin{abstract}
The introduced tree, Sapium sebiferum, is a serious invader throughout the southeastern United States. Low herbivore loads, commonly attributed to high herbivore resistance, are assumed to give Sapium a competitive advantage over native vegetation. Because herbivory resistance is considered energetically expensive, we predicted that if Sapium experienced higher levels of damage its growth would significantly decrease. We examined the effects of different levels of simulated leaf herbivory on the growth of Sapium and Celtis laevigata, a native tree, at three levels of nitrogen and three levels of light availability. Potted seedlings were grown in a complete factorial design. Stem height growth rate, diameter growth rate and plant mass of both Sapium and Celtis were significantly affected by shade and nitrogen treatments. Nitrogen increased the growth of both species and seedlings in shaded conditions grew larger than those in ambient sunlight. Simulated leaf herbivory had a significantly negative impact on diameter growth rate and plant mass of Celtis. Surprisingly, neither Sapium height growth rate, diameter growth rate, nor any measure of plant mass were significantly affected by simulated leaf herbivory. Rather, Sapium exhibited considerable phenotypic plasticity and was able to compensate for leaf damage in all resource conditions. Our findings suggest herbivory tolerance is a previously unappreciated trait of Sapium that, in conjunction with phenotypic plasticity and low levels of herbivory in its introduced range, likely contributes to its invasiveness.

Der eingeführte Baum, Sapium sebiferum, ist ein bedeutender Einwanderer in den gesamten südöstlichen Vereinigten Staaten. Es wird angenommen, dass eine geringe Herbivoren-Belastung Sapium einen Konkurrenzvorteil gegenüber der einheimischen Vegetation verschafft, die im Allgemeinen der hohen Herbivoren-Resistenz zugeschrieben wird. Weil Herbivoren-Resistenz als energetisch aufwändig betrachtet wird, sagten wir voraus, dass das Wachstum signifikant abnimmt, wenn Sapium einen höheren Grad der Beschädigung erfährt. Wir untersuchten die Auswirkungen unterschiedlicher Grade simulierter Herbivorie auf das Wachstum von Sapium und Celtis laevigata, einem einheimischen Baum, bei drei Niveaus der Stickstoff- und drei Niveaus der Lichtverfügbarkeit. Eingetopfte Keimlinge wurden in einem durchgehend faktoriellen Design kultiviert. Die Wachstumsraten der Stammhöhe und des Durchmessers sowie die Pflanzenmasse wurden bei Sapium und Celtis signifikant durch die Schatten- und Stickstoffbehandlungen beeinflusst. Stickstoff erhöhte das Wachstum bei beiden Arten und die Keimlinge wuchsen unter Schattenbedingungen höher als bei vollem Sonnenlicht. Simulierte Blattherbivorie hatte bei Celtis eine signifikant negative Einwirkung auf die Durchmesser-Wachstumsrate und die Pflanzenmasse. Überraschenderweise wurden bei Sapium weder die Höhen- und Durchmesser-Wachstumsrate, noch irgendein ein Maß für die Pflanzenmasse durch die simulierte Blattherbivorie signifikant beeinflusst. Stattdessen zeigte
\end{abstract}

*Corresponding author: William E. Rogers, Department of Ecology and Evolutionary Biology, Rice University, Houston, TX 77005, USA, Phone: +1-713-348-6338, Fax: +1-713-348-5232, E-mail: wer@rice.edu 
Sapium eine beachtliche phänotypische Plastizität und war in der Lage Blattbeschädigungen unter allen Ressourcen-Bedingungen zu kompensieren. Unsere Ergebnisse legen nahe, dass Herbivorietoleranz ein bisher nicht beachtetes Merkmal von Sapium ist, das wahrscheinlich in Verbindung mit der phänotypischen Plastizität und den geringen Graden der Herbivorie im neuen Verbreitungsgebiet zu seiner Invasivität beiträgt.

Key words: Chinese Tallow Tree - Sapium sebiferum - Texas Sugarberry - Celtis laevigata - compensatory response - herbivory tolerance - nitrogen fertilization - shade tolerance

\section{Introduction}

Understanding how different resource availabilities affect the growth of native and introduced plant species is essential for understanding invasiveness (Dukes \& Mooney 1999, Alpert et al. 2000, Davis et al. 2000). Increased nitrogen levels have been shown to promote invasions of native grasslands and temperate forests (e.g. Huenneke et al. 1990, Burke \& Grime 1996, Bakker \& Berendse 1999) and phenotypic plasticity in a wide range of light conditions contributes to the success of several invasive species (Bazzaz 1986, Williams et al. 1995, Pattison et al. 1998). Moreover, it is widely assumed that the competitive advantage displayed by introduced plants over native plants is partially due to differences in herbivore loads (e.g. Elton 1958, Crawley 1989, Tilman 1999). Because non-native plants are introduced with few or none of the specialist herbivores from their native habitat they gain a significant release from top-down regulation. Native plants are frequently observed with heavier herbivore loads than introduced plants (Strong et al. 1984, Schierenbeck et al. 1994, Yela \& Lawton 1997). These differences can greatly affect competitive outcomes since relatively small amounts of leaf herbivory can have major detrimental effects on plant growth and survival (Marquis 1992).

It has been proposed that a trade-off exists between the costs associated with maintaining herbivory resistance, the mechanisms that reduce the probability of defoliation, and herbivory tolerance, the mechanisms that facilitate regrowth following defoliation (e.g. van der Meijden et al. 1988, Herms \& Mattson 1992, Simms 1992, Fineblum \& Rausher 1995). Thus, herbivory resistant plants invest resources and energy that would otherwise be used for growth or reproduction in producing and maintaining costly chemical or physical herbivore deterrents. Herbivory tolerant plants suffer greater herbivore damage, but have high growth rates and possess morphological and physiological plasticity allowing them to rapidly regrow following defoliation and better compensate for mass lost to herbivory. Further, resource availability can affect plant allocation patterns, herbivore selectivity and how a plant responds to herbivore damage (Bazzaz et al. 1987, Trumble et al. 1993, Lill \& Marquis 2001, Stowe et al. 2001).

Chinese Tallow Tree (Sapium sebiferum (L.) Roxb., Euphorbiaceae) has recently become a major invader in the southeastern United States (Bruce et al. 1995, Jubinsky \& Anderson 1996). Once established, it is capable of aggressively displacing native plants and transforming native ecosystems into biotically depauperate woodland thickets (Bruce et al. 1997). Sapium's success as an invader is frequently attributed to a lack of pests and pathogens (Scheld \& Cowles 1981, Harcombe et al. 1993, Jubinsky \& Anderson 1996, Bruce et al. 1997). Observations support that Sapium loses very small amounts of leaf area to herbivory in the United States (Scheld \& Cowles 1981, Siemann \& Rogers 2001) and its leaves are presumed to contain costly secondary metabolites that repel herbivores (Cameron \& Spencer 1989, Jubinsky \& Anderson 1996).

Our objectives were to investigate the manner in which tree seedlings of Sapium sebiferum, believed to be herbivory resistant, respond to different levels of simulated leaf herbivory in various nitrogen and shade conditions. For comparison, we also examined Texas Sugarberry (Celtis laevigata (L.) Willd., var. texana (Scheele) Sarg.-Gates, Ulmaceae), an ecologically similar, albeit herbivory tolerant, native tree species. We hypothesized that if Sapium experienced levels of herbivory higher than typically experienced in its introduced range, it would show significant decreases in growth. In other words, although resistant to herbivore attacks, Sapium would lack herbivory tolerance. Additionally, we predicted that Celtis, which is regularly damaged by folivorous herbivores in the southeastern United States, would be tolerant of minor defoliation and compensate for low levels of leaf damage in a variety of resource conditions. Finally, we predicted that high levels of defoliation would negatively affect the growth of both tree species, but higher nitrogen and higher light levels would allow the plants to partially compensate for damage. 


\section{Materials and methods}

\section{Focal tree species}

Sapium sebiferum, originally introduced into Georgia in 1772, has recently become a major invader throughout the southeastern United States (Bruce et al. 1995). It is monecious and has abundant insect pollinated flowers from April through June (Bruce et al. 1997). Fruits ripen from August to November, and although its forage value is questionable, seeds are dispersed by many bird species (Renne et al. 2000). The tree is deciduous, loses its leaves in autumn and has range limits largely determined by winter temperatures and aridity (Schopmeyer 1974, Bruce et al. 1997). Rapid growth, colorful fall foliage, attractive flowers, and seeds rich in oils have encouraged extensive planting of Sapium for ornamental purposes, biomass production, industrial oils, and a nectar crop (Scheld \& Cowles 1981). Unfortunately, it readily escapes from cultivation and Sapium invasions are threatening numerous ecosystems of the southeastern United States, including upland mesic forests, floodplain forests, and endangered coastal prairies (Bruce et al. 1995, Grace 1998, Harcombe et al. 1999).

The factors contributing to an introduced species' invasibility can be better understood by pairing it with a taxonomically or ecologically similar native species (Barrett \& Richardson 1986, Schierenbeck et al. 1994, Radford \& Cousens 2000). Although no native Euphorbiaceae tree exists for comparison, Celtis laevigata is a common native tree found in coastal prairies, recently abandoned agricultural fields, woodland thickets, and other habitats where Sapium is found (Cameron \& Spencer 1989, Bruce et al. 1995, Harcombe et al. 1999). Like Sapium, Celtis has a similar flowering and fruiting phenology and is insect pollinated and bird dispersed (Schopmeyer 1974). Both species tend to occur in wetter sites, are classified as shade tolerant, and have the potential to grow rapidly in a variety of resource conditions (Jones \& McLeod 1989, van Auken \& Lohstroh 1990, Bruce et al. 1995, Harcombe et al.1999). A 20year record of sapling growth and mortality in an East Texas floodplain forest reveal that Celtis is the most similar native species to Sapium (Paul Harcombe, Rice University, unpublished data). Likewise, after Sapium, Celtis is the second most abundant tree species establishing in coastal prairies and Sapium woodlands (Cameron \& Spencer 1989, Bruce et al. 1995). Celtis is readily consumed by a variety of insects (personal observation), but is considered tolerant of moderate levels of herbivory (van Auken \& Lohstroh 1990). Despite Celtis and Sapium not being taxonomically related, there is ecological relevance for comparing their responses to herbivory in different resource combinations because they share a similar niche along the Texas Gulf Coast.

\section{Experimental design}

We germinated seeds of Celtis and Sapium in singlecelled, $100 \mathrm{ml}$ cone-tainers ${ }^{\mathrm{TM}}$ (Stuewe \& Sons, Inc., Corvallis, OR, USA) in a greenhouse during AprilMay 1999. In late May, the cone- tainers were transferred outdoors and placed beneath a 50\% shade cloth in order to "harden-off" the seedlings. On 7 June, we selected similar-sized Sapium ( $\mathrm{n}=162)$ and Celtis ( $\mathrm{n}=162$ ) seedlings and individually transplanted them into 3 gallon (7.65 liter) Stuewe Treepots ${ }^{\mathrm{TM}}$. To improve water retention approximately $3 \mathrm{~cm}$ of peat moss was placed in the bottom of the pots before filling them with a homogenized mixture of commercially available topsoil, organic humus and peat. We randomly assigned treatments to each of the 162 plants of each species in a full-factorial experimental design with three levels of simulated herbivory, three levels of nitrogen fertilizer addition, and three levels of shade (Table 1). We moved the pots to the roof of the biological sciences building on the Rice University campus on 9 June (designated as time 0 ) and measured stem height of each newly potted seedling from the soil surface to the tip of the apical meristem, stem diameter at the soil surface, and counted the number of leaves on each seedling. The tar-shingled roof was covered with wood chip-board to reduce albedo. The pots were placed in plastic water catches and watered daily.

In the shaded treatments, we placed the plants beneath black polypropylene shade cloths which attenuated $63 \%$ (S1) and $88 \%$ (S2) of photosynthetically active radiation (PAR) under clear skies during solar

Table 1. Experimental treatment manipulations. All potted Celtis and Sapium tree seedlings were randomly assigned to treatment combinations in a full-factorial experimental design $(n=3$ shade treatments $\times 3$ nitrogen treatments $\times 3$ herbivory treatments $\times 6$ replicates $=162$ of each species).

\begin{tabular}{|c|c|c|}
\hline $\begin{array}{l}\text { Shade } \\
\text { Treatments (S) }\end{array}$ & $\begin{array}{l}\text { Nitrogen } \\
\text { Treatments (N) }\end{array}$ & $\begin{array}{l}\text { Herbivory } \\
\text { Treatments (H) }\end{array}$ \\
\hline $\begin{array}{l}\text { SO }=100 \% \\
\text { ambient sunlight }\end{array}$ & $\begin{array}{l}\mathrm{NO}=0 \mathrm{gN} / \mathrm{m}^{2} \\
\text { as } \mathrm{NH}_{4} \mathrm{NO}_{3}\end{array}$ & $\begin{array}{l}\mathrm{HO}=\text { no simulated } \\
\text { leaf herbivory }\end{array}$ \\
\hline $\begin{array}{l}\text { S1 }=37 \% \\
\text { ambient sunlight }\end{array}$ & $\begin{array}{l}\mathrm{N} 1=3 \mathrm{gN} / \mathrm{m}^{2} \\
\text { as } \mathrm{NH}_{4} \mathrm{NO}_{3}\end{array}$ & $\begin{array}{l}\mathrm{H} 1=10 \% \text { leaf removal } \\
\text { (trial 1), } \\
60 \text { hole punches (trial 2) }\end{array}$ \\
\hline $\begin{array}{l}\mathrm{S} 2=12 \% \\
\text { ambient sunlight }\end{array}$ & $\begin{array}{l}\mathrm{N} 2=9 \mathrm{gN} / \mathrm{m}^{2} \\
\text { as } \mathrm{NH}_{4} \mathrm{NO}_{3}\end{array}$ & $\begin{array}{l}\mathrm{H} 2=20 \% \text { leaf removal } \\
\text { (trial 1), } \\
120 \text { hole punches (trial 2) }\end{array}$ \\
\hline
\end{tabular}


noon, as measured with a Decagon Accupar linear PAR ceptometer ${ }^{\mathrm{TM}}$ (Decagon Devices, Pullman, WA, USA)(Table 1). These values are representative of summer light environments at the soil surface in a coastal prairie $(62.4 \%$ less than ambient) and Sapium forest (88.2\% less than ambient), respectively. The pots were evenly spaced to prevent inter-plant shading and regularly rotated within their respective shade treatments.

We added nitrogen to the pots as ammonium nitrate dissolved in tap water. Plants assigned to fertilization treatments received either $1 \mathrm{gN} / \mathrm{m}^{2}$ (N1) or $3 \mathrm{gN} / \mathrm{m}^{2}$ (N2) during weeks two (17 June), six (15 July), and eleven (16 August) for $3 \mathrm{gN} / \mathrm{m}^{2}$ or $9 \mathrm{gN} / \mathrm{m}^{2}$ total respectively (Table 1 ). These values approximate increased amounts of nitrogen added to the soil annually due to rapid decay of Sapium leaf litter and three times that amount (Cameron \& Spencer 1989).

Small holes, presumably created by chewing insects, are the most common form of leaf herbivory observed on naturally growing Celtis and Sapium seedlings. Thus, we simulated leaf damage with a steel hole punch (6.3 mm diameter). Separate hole punchers were used for Celtis and Sapium to prevent possible transmission of disease or allelochemicals. Realistic simulation of herbivory by mechanical means is problematic because many aspects of insect chewing cannot be accurately duplicated (Hendrix 1988, Karban \& Baldwin 1997, Agrawal 1998). However, this type of simulated herbivory can provide an adequate representation of the decreased leaf area and mass loss experienced by insect damaged plants (Marquis 1992, Tiffin \& Inouye 2000).

We simulated leaf herbivory twice during the experiment. Plants assigned to simulated herbivory treatments were initially subjected to $10 \%$ leaf removal (H1) and 20\% leaf removal (H2) during week three (28 June) when all of the seedlings were of similar size (Table 1). Leaf area was estimated by measuring the length and width of three leaves per plant (near the top, middle, and bottom) and multiplying by the total number of leaves. Estimated leaf area of Sapium seedlings $\left(89.2 \pm 2.2 \mathrm{~mm}^{2}\right)$ was greater than the leaf area of Celtis seedlings $\left(54.8 \pm 1.5 \mathrm{~mm}^{2}\right)$ prior to the first simulated herbivory trial so more holes were punched in the Sapium leaves for the first trial. Average number of leaf holes $( \pm 1 \mathrm{SE})$ punched for $\mathrm{H} 1$ and $\mathrm{H} 2$ in the first trial were $18.11 \pm 0.65$ and $33.37 \pm 1.43$ for Sapium and $11.04 \pm 0.55$ and $21.00 \pm 0.92$ for Celtis respectively. To prevent bias against plants that responded positively to the resource manipulations, all seedlings received 60 hole punches for the $\mathrm{H} 1$ treatment and 120 hole punches for the $\mathrm{H} 2$ treatment in the second simulated herbivory trial during week nine (5 August). Damaging the plants a second time allowed us to magnify the negative effects of the simulated herbivory, particularly if the plants possess inducible defenses that were activated by the initial leaf damage (Karban $\&$ Baldwin 1997). Inducible defenses can increase a plant's fitness in the presence of herbivores (Agrawal 1998), but can be costly if it does not deter future herbivore attacks. We randomly and independently assigned hole punches based on the total number of leaves (and estimated leaf area in the first trial) per plant. When possible, midveins were not punched in order to prevent unintended magnification of the damage. We also excluded new leaves near the top of each seedling in order to protect the apical meristems and avoid unintentionally influencing branching dynamics (Marquis 1992). The fourth and fifth leaves on each plant were left undamaged so that leaf geometry and stomatal conductance measurements could be made on intact leaves for a separate study (Rogers et al. 2000).

Although herbivores were scarce on the $4^{\text {th }}$ story roof, we periodically sprayed Esfenvalerate ${ }^{\mathrm{TM}}$ (tradename Asana XL, DuPont Agricultural Products, Wilmington, DE) on the plants and surrounding area to ensure uncontrolled background herbivory on the tree seedlings did not occur. Separate phytotoxicity tests showed no negative effects of this insecticide on the plant mass of Celtis or Sapium seedlings (Siemann \& Rogers, unpublished data).

On 17 September, after 105 days (15 weeks) from the start of the experiment, we measured stem heights and diameters and harvested the plants. Leaves (including petioles) were clipped from the stems and branches. Plant stems (including branches) were clipped at the soil base and roots were gently washed from the soil. Root growth did not reach the bottom of any pot, thus, none of the seedlings appeared to be growth-limited by rooting space. Leaves, stems and roots were dried at $60{ }^{\circ} \mathrm{C}$ for $72 \mathrm{hrs}$ and weighed separately.

\section{Data analysis}

Stem height and diameter are expressed as relative growth rates $(g=\ln ($ final/initial $))$ where initial height and diameter were measured on 9 June prior to initiation of the experimental treatments and final height and diameter were measured on 17 September prior to harvesting the plants. Analysis of variance was used to compare measurements of tree growth and plant mass among the different experimental treatments (StatView 5.0, SAS Institute, Cary, NC). In order to meet the assumptions of ANOVA, data for all measures of plant mass were natural log transformed for statistical analyses and back-transformed for graphical presentation. 


\section{Results}

At the time the seedlings were transplanted mean $( \pm 1$ SE) stem heights, diameters, and number of leaves were $132.6 \pm 2.1 \mathrm{~mm}, 1.9 \pm 0.03 \mathrm{~mm}$, and $11.7 \pm 0.2$ leaves respectively for Celtis $(\mathrm{n}=162)$ and $155.0 \pm 1.5$ $\mathrm{mm}, 3.1 \pm 0.03 \mathrm{~mm}$, and $11.1 \pm 0.1$ leaves respectively for Sapium ( $\mathrm{n}=162)$. Due to sustained size differences a direct statistical comparison was not performed between Celtis and Sapium. All 324 seedlings survived for the duration of the experiment.

Celtis height growth rate was significantly affected by a shade* nitrogen interaction (Table 2A). The combination of increased shade and increased nitrogen promoted increases in height growth rate of Celtis, particularly in high nitrogen (N2) and intermediate shade (S1) conditions (Fig. 1A). Sapium height growth rate was significantly affected by shade and nitrogen main effects (Table 2B). Both levels of shade (S1 \& S2) significantly increased Sapium height growth rate compared to ambient sunlight (SO), while the highest level of nitrogen addition (N2) significantly increased Sapium height growth rate more than lower nitrogen (N0 \& N1) treatments (Fig. 1B). Neither Celtis nor Sapium height growth rates were affected by simulated herbivory as a main effect or in interaction with shade or nitrogen (Table 2).

The main effects of shade, nitrogen and simulated herbivory all significantly influenced Celtis diameter growth rate (Fig. 2A, Table 2A). Both shade (S1 \& S2) and both nitrogen (N1 \& N2) levels increased Celtis diameter growth rate compared to controls (Fig. 2A). Conversely, both levels of simulated herbivory (H1 \& H2) significantly decreased Celtis diameter growth rate compared to undamaged controls (Fig. 2A). Sapium stem diameter growth rate was significantly affected by a shade* nitrogen interaction (Table $2 \mathrm{~B}$ ). Intermediate levels of shade (S1) significantly increased Sapium diameter growth rate more than ambient sunlight (S0) or high shade (S2) while the highest nitrogen (N2) level significantly increased Sapium diameter growth rate more than lower nitrogen (N0 \& N1) lev-
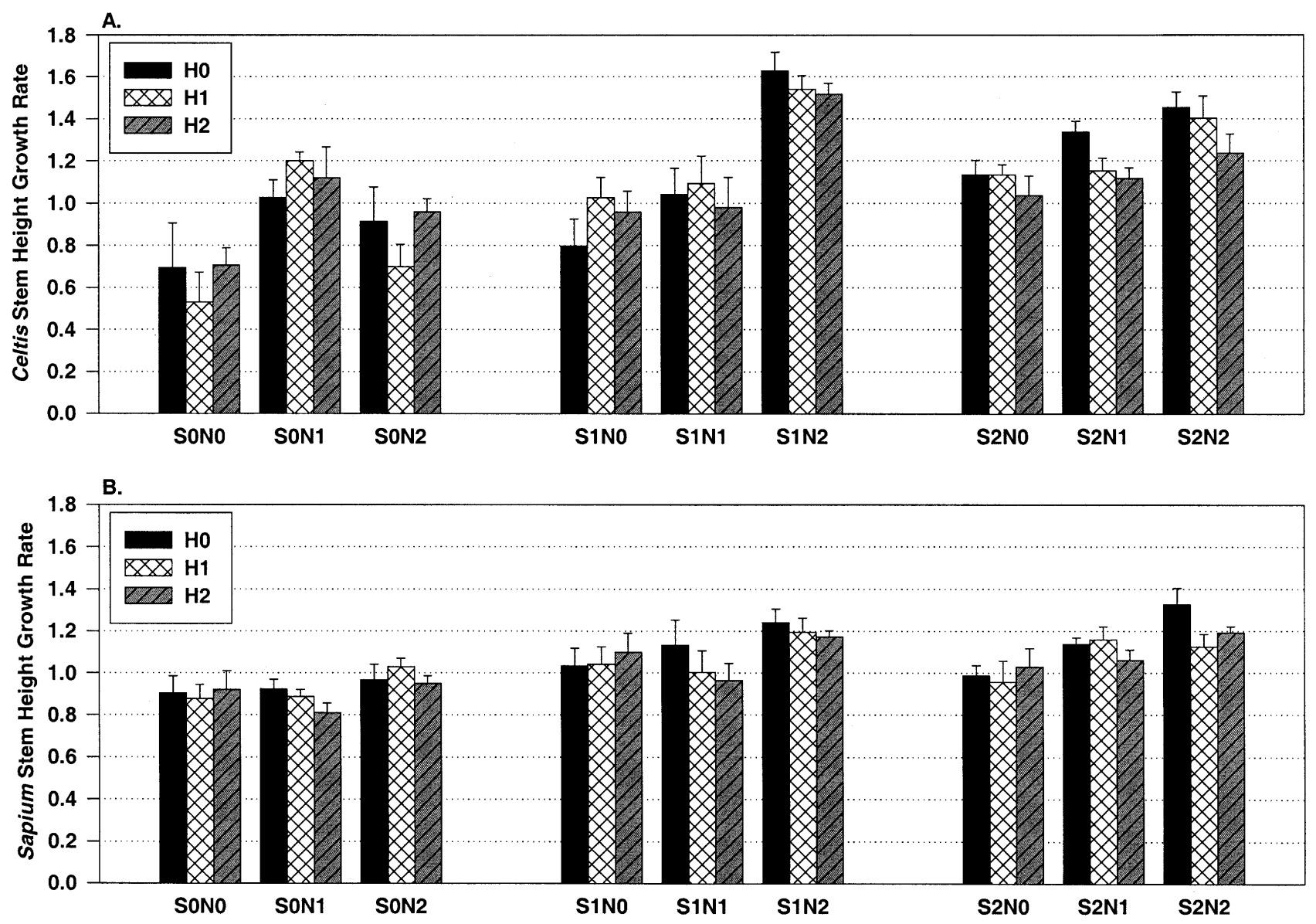

Fig. 1. Mean stem height growth rate $(+1$ SE) for A) Celtis laevigata $(n=162)$ and B) Sapium sebiferum $(n=162)$ tree seedlings grown for fifteen weeks in full-factorial combinations of three shade $(S)$, three nitrogen $(N)$, and three simulated herbivory $(H)$ treatments. 
Table 2. Three-way analyses of variance tables comparing stem height growth rates and stem diameter growth rates for A) Celtis laevigata and B) Sapium sebiferum tree seedling responses to the experimental treatments: $\mathrm{S}=$ shade treatments, $\mathrm{N}=$ nitrogen addition treatments, and $\mathrm{H}=$ simulated herbivory treatments (see Figs. 1 and 2). Growth rate $=$ In(final/initial).

\begin{tabular}{|c|c|c|c|c|c|c|c|}
\hline \multirow{3}{*}{$\begin{array}{l}\text { A. } \\
\text { source of variation }\end{array}$} & \multirow[b]{3}{*}{$d f$} & \multicolumn{6}{|c|}{ Celtis laevigata } \\
\hline & & \multicolumn{3}{|c|}{ Stem Height Growth Rate } & \multicolumn{3}{|c|}{ Stem Diameter Growth Rate } \\
\hline & & $\overline{M S}$ & $\mathrm{~F}$ & $P$ & $\overline{M S}$ & $\mathrm{~F}$ & $P$ \\
\hline S & 2 & 1.962 & 29.80 & $* * * *$ & 0.372 & 9.63 & $* * * *$ \\
\hline N & 2 & 1.885 & 28.63 & $* * * *$ & 1.060 & 27.43 & $* * * *$ \\
\hline $\mathrm{H}$ & 2 & 0.026 & 0.40 & ns & 0.216 & 5.59 & $* *$ \\
\hline$S^{*} \mathrm{~N}$ & 4 & 0.755 & 11.47 & $* * * *$ & 0.059 & 1.53 & ns \\
\hline $\mathrm{S}^{*} \mathrm{H}$ & 4 & 0.103 & 1.57 & ns & 0.026 & 0.66 & ns \\
\hline $\mathrm{N}^{*} \mathrm{H}$ & 4 & 0.038 & 0.58 & ns & 0.022 & 0.58 & ns \\
\hline $\mathrm{S}^{*} \mathrm{~N} * \mathrm{H}$ & 8 & 0.053 & 0.81 & ns & 0.017 & 0.44 & ns \\
\hline residual & 135 & 0.066 & & & 0.039 & & \\
\hline \multirow{3}{*}{$\begin{array}{l}\text { B. } \\
\text { source of variation }\end{array}$} & & \multicolumn{6}{|c|}{ Sapium sebiferum } \\
\hline & & \multicolumn{3}{|c|}{ Stem Height Growth Rate } & \multicolumn{3}{|c|}{ Stem Diameter Growth Rate } \\
\hline & $d f$ & $\overline{M S}$ & $\mathrm{~F}$ & $P$ & $\overline{M S}$ & $\mathrm{~F}$ & $P$ \\
\hline S & 2 & 0.613 & 20.61 & $* * * *$ & 0.206 & 11.51 & $* * * *$ \\
\hline N & 2 & 0.345 & 11.59 & $* * * *$ & 0.308 & 17.21 & $* * * *$ \\
\hline $\mathrm{H}$ & 2 & 0.039 & 1.31 & ns & 0.052 & 2.94 & ns \\
\hline$S^{*} \mathrm{~N}$ & 4 & 0.044 & 1.47 & ns & 0.046 & 2.57 & * \\
\hline$S^{*} \mathrm{H}$ & 4 & 0.007 & 0.23 & ns & 0.021 & 1.18 & ns \\
\hline $\mathrm{N}^{*} \mathrm{H}$ & 4 & 0.034 & 1.15 & ns & 0.006 & 0.33 & ns \\
\hline$S * N * H$ & 8 & 0.015 & 0.50 & ns & 0.019 & 1.04 & ns \\
\hline residual & 135 & 0.030 & & & 0.018 & & \\
\hline
\end{tabular}

P-value: ns $=$ not significant; ${ }^{*}=\leq 0.05 ;{ }^{* *}=\leq 0.01 ;{ }^{* * *}=\leq 0.001 ;{ }^{* * *}=\leq 0.0001$

Table 3. Three-way analysis of variance tables comparing In(shoot mass), In(root mass), and In(root:shoot) ratios for A) Celtis laevigata and B) Sapium sebiferum to the experimental treatments: $\mathrm{S}$ = shade, $\mathrm{N}=$ nitrogen additions, $\mathrm{H}=$ simulated herbivory (see Fig. 3).

\begin{tabular}{|c|c|c|c|c|c|c|c|c|c|c|}
\hline \multirow{3}{*}{$\begin{array}{l}\text { A. } \\
\text { source of variation }\end{array}$} & \multirow[b]{3}{*}{$d f$} & \multicolumn{9}{|c|}{ Celtis laevigata } \\
\hline & & \multicolumn{3}{|c|}{$\ln$ (Shoot Mass) } & \multicolumn{3}{|c|}{$\ln$ (Root Mass) } & \multicolumn{3}{|c|}{$\ln$ (Root:Shoot) } \\
\hline & & MS & $F$ & $P$ & MS & $\mathrm{F}$ & $P$ & MS & $F$ & $P$ \\
\hline$S$ & 2 & 6.436 & 27.17 & $* * * *$ & 4.185 & 27.79 & $* * * *$ & 2.764 & 21.21 & $* * * *$ \\
\hline N & 2 & 11.41 & 48.17 & $* * * *$ & 4.921 & 32.68 & $* * * *$ & 1.408 & 10.81 & $* * * *$ \\
\hline $\mathrm{H}$ & 2 & 2.079 & 8.78 & $* * *$ & 1.814 & 12.05 & $* * * *$ & 0.015 & 0.11 & ns \\
\hline $\mathrm{S}^{*} \mathrm{~N}$ & 4 & 1.742 & 7.35 & $* * * *$ & 1.686 & 11.20 & $* * * *$ & 0.282 & 2.17 & ns \\
\hline $\mathrm{S}^{*} \mathrm{H}$ & 4 & 0.658 & 2.78 & $*$ & 0.560 & 3.72 & $* *$ & 0.114 & 0.88 & ns \\
\hline $\mathrm{N}^{*} \mathrm{H}$ & 4 & 0.193 & 0.82 & ns & 0.339 & 2.25 & ns & 0.134 & 1.03 & ns \\
\hline$S^{*} N^{*} H$ & 8 & 0.375 & 1.59 & ns & 0.489 & 3.25 & ** & 0.103 & 0.79 & ns \\
\hline residual & 135 & 0.237 & & & 0.151 & & & 0.130 & & \\
\hline \multirow{3}{*}{$\begin{array}{l}\text { B. } \\
\text { source of variation }\end{array}$} & & \multicolumn{9}{|c|}{ Sapium sebiferum } \\
\hline & & \multicolumn{3}{|c|}{$\ln$ (Shoot Mass) } & \multicolumn{3}{|c|}{ In(Root Mass) } & \multicolumn{3}{|c|}{$\ln$ (Root:Shoot) } \\
\hline & $d f$ & MS & $\mathrm{F}$ & $P$ & MS & $F$ & $P$ & MS & $\mathrm{F}$ & $P$ \\
\hline S & 2 & 1.871 & 8.73 & $* * *$ & 3.267 & 18.26 & $* * * *$ & 1.699 & 52.06 & $* * * *$ \\
\hline N & 2 & 5.040 & 23.52 & $* * * *$ & 2.665 & 14.89 & $* * * *$ & 0.456 & 13.96 & $* * * *$ \\
\hline $\mathrm{H}$ & 2 & 0.115 & 0.54 & ns & 0.351 & 1.96 & ns & 0.067 & 2.07 & ns \\
\hline$S^{*} N$ & 4 & 0.191 & 0.89 & ns & 0.129 & 0.72 & ns & 0.088 & 2.70 & * \\
\hline $\mathrm{S}^{*} \mathrm{H}$ & 4 & 0.161 & 0.75 & ns & 0.132 & 0.74 & ns & 0.023 & 0.71 & ns \\
\hline $\mathrm{N}^{*} \mathrm{H}$ & 4 & 0.265 & 1.24 & ns & 0.210 & 1.17 & ns & 0.038 & 1.18 & ns \\
\hline $\mathrm{S}^{*} \mathrm{~N} * \mathrm{H}$ & 8 & 0.210 & 0.98 & ns & 0.324 & 1.81 & ns & 0.054 & 1.66 & ns \\
\hline residual & 135 & 0.214 & & & 0.179 & & & 0.033 & & \\
\hline
\end{tabular}

P-value: $n s=$ not significant; ${ }^{*}=\leq 0.05 ;{ }^{* *}=\leq 0.01 ;{ }^{* * *}=\leq 0.001 ;{ }^{* * * *}=\leq 0.0001$ 
els (Fig. 2B). Sapium diameter growth rate was not significantly affected by simulated herbivory treatments (Table 2B, Fig. 2B). Simulated herbivory damage did not significantly alter branch numbers or architecture of either species.

Because separate leaf mass and stem mass analyses exhibited similar statistical responses to the experimental treatments (not shown) these measures were combined and analyzed as shoot mass (Table 3 ). Celtis shoot mass and root mass were significantly affected by shade, nitrogen and simulated herbivory treatments (Table 3A). While nitrogen and shade tended to increase Celtis mass, the effect was lessened by increased herbivory damage (Fig. 3A). Celtis root:shoot mass was significantly affected by main effects of shade and nitrogen (Table 3A). Both shade and nitrogen tended to decrease Celtis root:shoot mass (Fig. 3A). Simulated herbivory did not significantly affect Celtis root:shoot mass because it decreased roots and shoots similarly (Table 3A, Fig. 3A). Only shade and nitrogen significantly affected Sapium shoot mass and root mass (Table 3B). Both shade and nitrogen tended to increase
Sapium mass with the greatest effect at high nitrogen (N2) and intermediate shade (S1) levels (Fig. 3B). Sapium root:shoot mass was significantly decreased by shade and nitrogen (Table 3B, Fig. 3B). No measure of Sapium mass was significantly affected by simulated herbivory treatments (Table $3 \mathrm{~B}$ ).

\section{Discussion}

Phenotypic plasticity has been identified as a fundamental trait contributing to the invasiveness of nonnative plants (e.g. Bazzaz 1986, Alpert et al. 2000). Our results support assertions that Sapium's ability to thrive under a variety of environmental conditions likely contributes to its dramatic success as an invader of multiple habitats throughout the southeastern United States (Jubinsky \& Anderson 1996, Bruce et al. 1997, Grace 1998, Harcombe et al. 1999). Further, the lack of a negative effect of simulated herbivory on Sapium's growth suggests that herbivory tolerance, expressed as phenotypic plasticity and rapid compen-

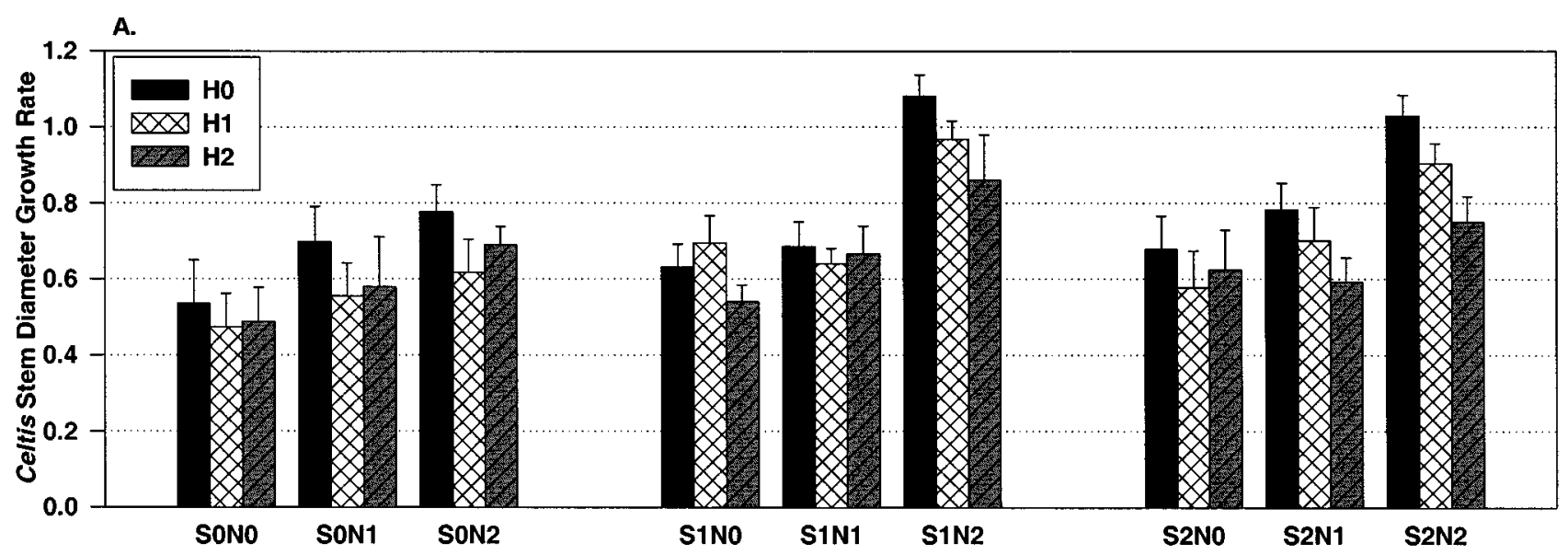

B.

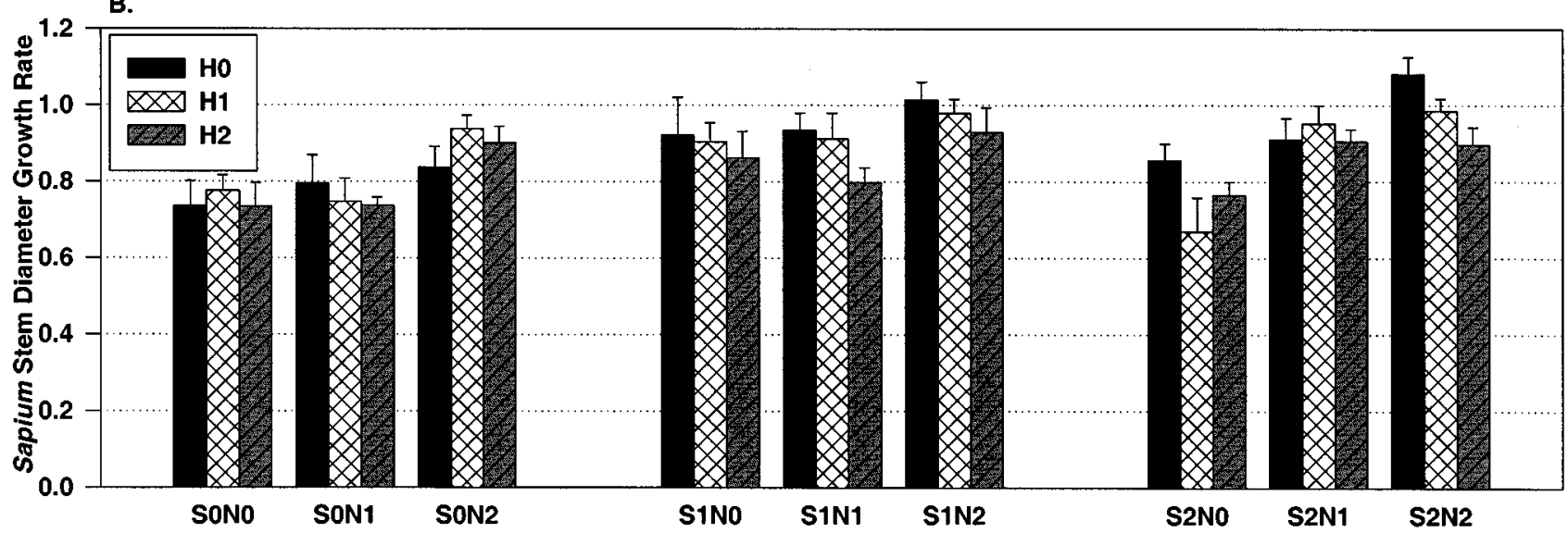

Fig. 2. Mean stem diameter growth rate ( +1 SE) for A) Celtis laevigata $(n=162)$ and B) Sapium sebiferum $(n=162)$ tree seedlings grown for fifteen weeks in full-factorial combinations of three shade $(\mathrm{S})$, three nitrogen $(\mathrm{N})$, and three simulated herbivory $(\mathrm{H})$ treatments. 
satory regrowth, rather than costly herbivory resistance is a potentially unappreciated trait contributing to Sapium invasion.

\section{Effects of resources}

Shade treatments significantly affected both species. Previous research examining Celtis and Sapium responses to various light conditions supports the generalization that these species are shade tolerant (Jones \& McLeod 1989, 1990, Bush \& van Auken 1995, Harcombe et al. 1999). Since shade tolerant tree species grow only slightly faster in high than low light (e.g. Loach 1970, Pearcy \& Sims 1994), we expected comparable growth across our experimental light levels. Unexpectedly, growth was significantly lower in ambient sunlight for both Sapium and Celtis. This may potentially be explained by periods of photoinhibition or photooxidation induced by temperature and water stresses in full sunlight (Pearcy \& Sims 1994) despite the tree seedlings being watered daily. Both Sapium and Celtis sustained vigorous stem growth in shaded conditions. The marked height growth rate of Celtis in low light may lead to the mistaken conclusion that Celtis is more shade tolerant than Sapium. However, the comparatively small stem diameters of Celtis seedlings were often unable to support the plants in an erect position. Thus, although the etiolated Celtis stems were occasionally longer than Sapium stems, Celtis seedlings were often drooping which reduced their height in relation to a hypothetical plant canopy and presumably would reduce their ability to compete for limited light in shaded conditions. The comparatively thicker, heavier stems of Sapium kept these tree seedlings erect and provided them with a greater functional height than Celtis. This likely has important implications for competitive interactions of Sapium with native vegetation in the shaded conditions of prairie litter and forest under-

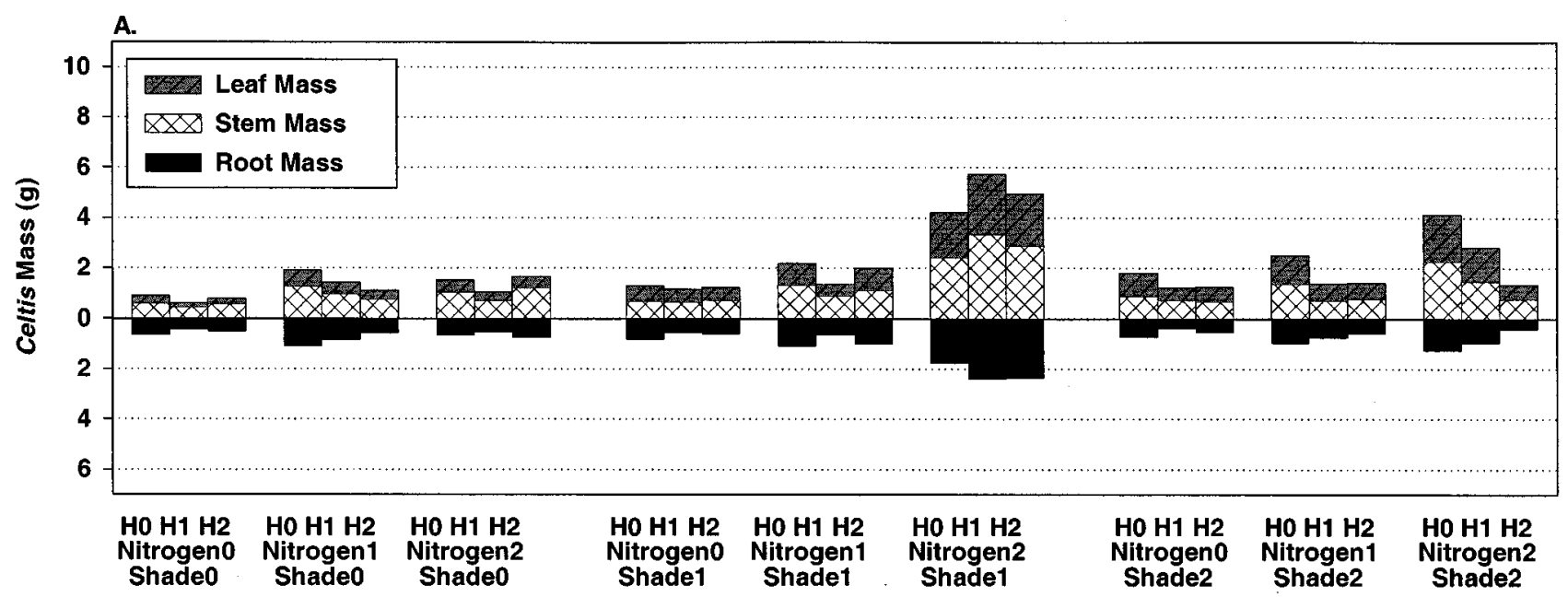

B.

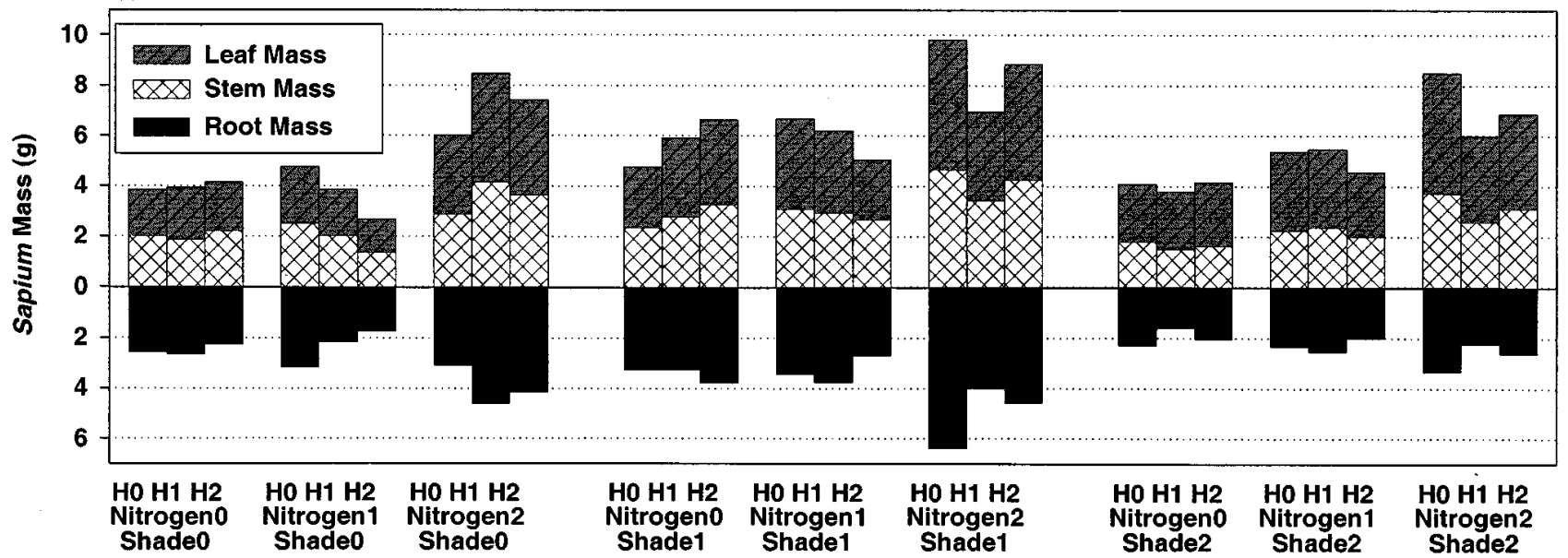

Fig. 3. Mean leaf, stem and root mass for A) Celtis laevigata $(n=162)$ and B) Sapium sebiferum $(n=162)$ tree seedlings grown for fifteen weeks in full-factorial combinations of three shade $(S)$, three nitrogen $(N)$, and three simulated herbivory $(H)$ treatments. 
stories that these experimental shade treatments represent (Bruce et al. 1995). Others have shown that, relative to a variety of shade tolerant and intolerant tree species, Sapium exhibits considerable morphological plasticity that promotes superior growth in many light conditions (Jones \& McLeod 1989, 1990).

As expected, both Celtis and Sapium showed strong, positive growth responses to increased nitrogen (Scheld \& Cowles 1981, Cameron \& Spencer 1989, Bush \& van Auken 1995). This effect is particularly likely to be reinforced by litter feedbacks in Sapium's invasion of grasslands. Cameron \& Spencer (1989) have shown that the rapid decomposition of Sapium litter makes available nitrogen concentrations under Sapium trees nearly double that beneath native prairie. Again, however, Celtis height increases attributable to nitrogen, particularly in shaded conditions, often caused the etiolated stems to hang down while Sapium stems remained erect.

\section{Effects of simulated herbivory}

Simulated leaf herbivory did not decrease Sapium growth as predicted. Rather, it was less affected by leaf damage than Celtis, the herbivory tolerant species. Celtis showed significantly negative effects of simulated herbivory on stem diameter growth rate and plant mass, while Sapium's stem growth rate and plant mass were unaffected. However, in accordance with carbonnutrient balance theory, high nutrient levels did allow mechanically damaged Celtis seedlings to compensate for lost leaf mass (Coley et al. 1985, Bazzaz et al. 1987). Additional field studies are necessary to determine whether leaf quality is affected in such a way that herbivore selectivity and consumption are increased on fertilized seedlings (Coley et al. 1985, Bazzaz et al. 1987, Trumble et al. 1993).

We also predicted that increased light availability would increase the relative growth of defoliated plants. Although Sapium seedlings were not affected by herbivory treatments, negative effects of herbivory on Celtis were magnified by high shade levels. This effect could be intensified when actual herbivores, rather than mechanically damaged leaves, differentially exploit environmentally stressed seedlings (Strong et al. 1984, Louda et al. 1990, Marquis 1992).

\section{Implications for Sapium as an invasive exotic species}

Sapium's success as an invader is frequently attributed to an absence of pests and pathogens (Scheld \& Cowles 1981, Cameron \& Spencer 1989, Bruce et al. 1995, Jubinsky \& Anderson 1996) with the connotation that Sapium is resistant to native herbivores. Our results suggest that Sapium is a herbivory tolerant plant in North America that rapidly compensates for mass lost to defoliation. A previously unappreciated explanation for Sapium's success as an invader may be that as a herbivory tolerant species without an appreciable herbivore load, it is experiencing the benefits of a herbivore resistant plant without incurring the associated costs of resistance (e.g. van der Meijden et al. 1988, Simms 1992, Rosenthal \& Kotanen 1994, Strauss \& Agrawal 1995, Stowe et al. 2001). In other words, Sapium may not be experiencing a trade-off between herbivory resistance and herbivory tolerance like other native plant species because it has escaped the "to grow or defend" dilemma of plants in its introduced range by allocating resources toward growth rather than defense (sensu Herms \& Mattson 1992). Other researchers have suggested that a population of introduced plants freed from their native herbivores might lose adaptations to herbivory over time (Blossey \& Nötzold 1995, Daehler \& Strong 1997, Willis et al. 2000, Mooney \& Cleland 2001). This interpretation is consistent with our recent findings from a study examining Sapium trees grown from invasive North American genotypes and native Asian genotypes (Siemann \& Rogers 2001). Texas genotypes were significantly larger and more likely to produce seeds than Asian genotypes. Conversely, Asian genotypes had significantly higher quality foliage that contained higher concentrations of secondary defense chemicals. Neither of these genotypes suffered appreciable leaf herbivory in field conditions, but grasshoppers placed in enclosures with Texas Sapium seedlings readily consumed the foliage, suggesting that low damage levels are partially due to behavioral constraints of the local herbivore fauna and not foliar toxicity (unpublished data). Further studies are necessary to determine whether other types of herbivory (e.g. phloem feeders, root herbivores) could potentially regulate Sapium's growth or whether the effects of damage become manifest over greater time scales (Hunter 2001, Scheu 2001). Also, competition for limited resources in the presence of native vegetation may modify its allocation patterns and affect Sapium's ability to compensate for herbivory (Maschinski \& Whitham 1989, Louda et al. 1990, Hunter \& Price 1992). Nevertheless, our study suggests that the ability to thrive in a variety of environmental conditions, low herbivory damage and rapid compensatory regrowth all likely contribute to Sapium's invasiveness in its introduced range.

Acknowledgements: The authors would like to thank C Jones, J Keay, R Lankau, E Loggins, S McCarthy, C Naficy, $\mathrm{S}$ Nijjer, C Smith and E Wu for assistance. J Grace and P Harcombe provided helpful comments on the study. Support for this research was provided by the US National Science Foundation. 


\section{References}

Agrawal AA (1998) Induced responses to herbivory and increased plant performance. Science 279: 1201-1202.

Alpert P, Bone E, Holzapfel C (2000) Invasiveness, invasibility and the role of environmental stress in the spread of non-native plants. Perspectives in Plant Ecology, Evolution and Systematics 3: 52-66.

Bakker JP, Berendse F (1999) Constraints in the restoration of ecological diversity in grassland and heathland communities. Trends in Ecology and Evolution 14: 63-68.

Barrett S, Richardson B (1986) Genetic attributes of invading species. In: Groves R, Burdon J (eds) Ecology of biological invasions, Cambridge University Press, Melbourne, pp 21-33.

Bazzaz FA (1986) Life history of colonizing plants: some demographic, genetic, and physiological features. In: Mooney HA, Drake JA (eds) Ecology of biological invasions of North America and Hawaii. Springer-Verlag, New York, pp 96-110.

Bazzaz FA, Chiariello NR, Coley PD, Pitelka LF (1987) Allocating resources to reproduction and defense. BioScience 37: 58-67.

Blossey B, Nötzold R (1995) Evolution of increased competitive ability in invasive nonindigenous plants: a hypothesis. Journal of Ecology 83: 887-889.

Bruce KA, Cameron GN, Harcombe PA (1995) Initiation of a new woodland type on the Texas Coastal Prairie by the Chinese tallow tree (Sapium sebiferum (L.) Roxb.). Bulletin of the Torrey Botanical Club 122: 215-225.

Bruce KA, Cameron GN, Harcombe PA, Jubinsky G (1997) Introduction, impact on native habitats, and management of a woody invader, the Chinese Tallow Tree, Sapium sebiferum (L.) Roxb. Natural Areas Journal 17: 255-260.

Burke MJW. Grime JP (1996) An experimental study of plant community invasibility. Ecology 77: 776-790.

Bush, JK van Auken OW (1995) Interactions between seedlings of an early and a late successional woody species. Southwestern Naturalist 40: 379-387.

Cameron GN, Spencer SR (1989) Rapid leaf decay and nutrient release in a Chinese tallow forest. Oecologia 80: 222-228.

Coley PD, Bryant JP, Chapin FS (1985) Resource availability and plant antiherbivore defense. Science 230: 895-899.

Crawley MJ (1989) Insect herbivores and plant population dynamics. Annual Review of Entomology 34: 531-64.

Daehler CC, Strong DR (1997) Reduced herbivore resistance in introduced smooth cordgrass (Spartina alterniflora) after a century of herbivore-free growth. Oecologia 110: 99-108.

Davis, MA, Grime, JP, Thompson, K (2000) Fluctuating resources in plant communities: a general theory of invasibility. Journal of Ecology 88: 528-534.

Dukes JS, Mooney HA (1999) Does global change increase the success of biological invaders? Trends in Ecology and Evolution 14: 135-139.

Elton CS (1958) The ecology of invasion by plants and animals. Chapman and Hall, London.
Fineblum WL, Rausher MD (1995) Tradeoff between resistance and tolerance to herbivore damage in a morning glory. Nature 377: 517-520.

Grace JB (1998) Can prescribed fire save the endangered coastal prairie ecosystem from Chinese tallow invasion? Endangered Species Update 15: 70-76.

Harcombe PA, Hall RBW, Glitzenstein JS, Cook ES, Krusic P, Fulton M, Streng DR (1999) Sensitivity of Gulf Coast forests to climate change. In: Guntenspergen G, Vairin BA (eds) Vulnerability of coastal wetlands in the southeastern United States. Biological Science Report USGS/BRD/BSR1998-0002, pp 45-66.

Harcombe PA, Cameron GN, Glumac EG (1993) Aboveground net primary productivity in adjacent grassland and woodland on the coastal prairie of Texas. Journal of Vegetation Science 4: 521-530.

Hendrix SD (1988) Herbivory and its impact on plant reproduction. In: Lovett Doust J, Lovett Doust L (eds) Plant reproductive ecology: patterns and strategies. Oxford University Press, Oxford, pp 246-263.

Herms DA, Mattson WJ (1992) The dilemma of plants: to grow or defend. Quarterly Review of Biology 67: 283-335.

Huenneke LF, Hamburg SP, Koide R, Mooney HA, Vitousek PM (1990) Effects of soil resources on plant invasion and community structure in California serpentine grassland. Ecology 71: 478-491.

Hunter MD (2001) Multiple approaches to estimating the relative importance of top-down and bottom-up forces on insect populations: Experiments, life tables, and time-series analyses. Basic and Applied Ecology 2: 293-294.

Hunter MD, Price PW (1992) Playing chutes and ladders: heterogeneity and the relative roles of bottom-up and topdown forces in natural communities. Ecology 73: 724-732.

Jones R, McLeod K (1989) Shade tolerance in seedlings of Chinese Tallow Tree, American Sycamore, and Cherrybark Oak. Bulletin of the Torrey Botanical Club 116: 371-377.

Jones R, McLeod K (1990) Growth and photosynthetic responses to a range of light environments in Chinese Tallow and Carolina Ash seedlings. Forest Science 36: 851-862.

Jubinsky G, Anderson LC (1996) The invasive potential of Chinese Tallow-tree (Sapium sebiferum Roxb.) in the southeast. Castanea 61: 226-231.

Karban R, Baldwin IT (1997) Induced responses to herbivory. University of Chicago Press, Chicago.

Lill JT, Marquis RJ (2001) The effects of leaf quality on herbivore performance and attack from natural enemies. Oecologia 126: 418-428.

Loach K (1970) Shade tolerance in tree seedlings II. growth analysis of plants raised under artificial shade. The New Phytologist 69: 273-286.

Louda SM, Keeler KH, Holt RD (1990) Herbivore influences on plant performance and competitive interactions. In: Grace JB, Tilman D (eds), Perspectives on plant competition. Academic Press, San Diego, pp. 413-444.

Marquis RJ (1992) The selective impact of herbivores. In: Fritz RS, Simms EL (eds) Plant resistance to herbivores 
and pathogens: ecology, evolution, and genetics. University of Chicago Press, Chicago, pp 301-325.

Maschinski J, Whitham T (1989) The continuum of plant responses to herbivory: influence of plant association, nutrient availability, and timing. American Naturalist 134: 1-19.

Mooney HA, Cleland EE (2001) The evolutionary impact of invasive species. Proceedings of the National Academy of Sciences USA 98: 5446-5451.

Pattison RR, Goldstein G, Ares A (1998) Growth, biomass allocation and photosynthesis of invasive and native Hawaiian rainforest species. Oecologia 117: 449-459.

Pearcy RW, Sims DA (1994) Photosynthetic acclimation to changing light environments: scaling from the leaf to the whole plant. In: Caldwell MM, Pearcy RW (eds) Exploitation of environmental heterogeneity by plants. Academic Press, San Diego, pp 145-174.

Radford IJ, Cousens RD (2000) Invasiveness and comparative life-history traits of exotic and indigenous Senecio species in Australia. Oecologia 125: 531-542.

Renne I, Gauthreaux SA, Gresham CA (2000) Seed dispersal of the Chinese tallow tree (Sapium sebiferum) by birds in coastal South Carolina. American Midland Naturalist 144: 202- 215.

Rogers WE, Nijjer S, Smith CL, Siemann E (2000) Effects of resources and herbivory on leaf morphology and physiology of Chinese tallow (Sapium sebiferum) tree seedlings. Texas Journal of Science 52S: 43-56.

Rosenthal JP, Kotanen PM (1994) Terrestrial plant tolerance to herbivory. Trends in Ecology and Evolution 9: 145-148.

Scheld HW, Cowles JR (1981) Woody biomass potential of the Chinese Tallow Tree. Economic Botany 35: 391-397.

Scheu S (2001) Plants and generalist predators as links between the below-ground and above-ground system. Basic and Applied Ecology 2: 3-13.

Schierenbeck KA, Mack RN, Sharitz RR (1994) Effects of herbivory on growth and biomass allocation in native and introduced species of Lonicera. Ecology 75: 1661-1672.

Schopmeyer CS (ed) (1974) Seeds of woody plants in the United States. Agricultural Handbook No. 450. Forest
Service, United States Department of Agriculture, Washington, DC.

Siemann E, Rogers WE (2001) Genetic differences in growth of an invasive tree species. Ecology Letters 4: 514-518.

Simms EL (1992) Costs of plant resistance to herbivory. In: Fritz RS, Simms EL (eds) Plant resistance to herbivores and pathogens: ecology, evolution, and genetics. University of Chicago Press, Chicago, pp 392-425.

Strauss SY, Agrawal AA (1995) The ecology and evolution of plant tolerance to herbivory. Trends in Ecology and Evolution 14: 179-185.

Stowe KA, Marquis RJ, Hochwender CG, Simms EL (2001) The evolutionary ecology of tolerance to consumer damage. Annual Review of Ecology and Systematics 31: 565-595.

Strong DR, Lawton JH, Southwood TRE (1984) Insects on plants. Harvard Press, Cambridge.

Tiffin P, Inouye BD (2000) Measuring tolerance to herbivory: accuracy and precision of estimates made using natural versus imposed damage. Evolution 54: 1024-1029.

Tilman D (1999) The ecological consequences of changes in biodiversity: a search for general principles. Ecology 80: 1455-1474.

Trumble JT, Kolodny-Hirsch DM, Ting IP (1993) Plant compensation for arthropod herbivory. Annual Review of Entomology 38: 93-119.

van Auken OW, Lohstroh RJ (1990) Importance of canopy position for growth of Celtis laevigata seedlings. Texas Journal of Science 42: 83-89.

van der Meijden E, Wijn H, Verkaar J (1988) Defense and regrowth, alternative plant strategies in the struggle against herbivores. Oikos 51: 355-363.

Williams DG, Mack RN, Black RA (1995) Ecophysiology of introduced Pennisetum setaceum on Hawaii: the role of phenotypic plasticity. Ecology 76: 1569-1580.

Willis AJ, Memmott J, Forrester RI (2000) Is there evidence for the post-invasion evolution of increased size among invasive plant species. Ecology Letters 3: 275-283.

Yela JL, Lawton JH (1997) Insect herbivore loads on native and introduced plants; a preliminary study. Entomologia Experimentalis et Applicata, 85: 275-279. 